\title{
8. CALCAREOUS NANNOFOSSIL BIOSTRATIGRAPHY OF SITE 953, CANARY BASIN, NORTHEASTERN NORTH ATLANTIC ${ }^{1}$
}

\author{
JoAnne Sblendorio-Levy² and Richard W. Howe ${ }^{3}$
}

\begin{abstract}
Site 953 in the Northeastern Atlantic, northeast of Gran Canaria, recovered an essentially complete Pleistocene to middle Miocene biostratigraphic record. Quantitative analysis of the calcareous nannofossils identified 57 calcareous nannofossil events. Forty-seven of these events have been tied, where possible, to the paleomagnetic record (Schmincke, Weaver, Firth, et al., 1995; B. Herr, pers. comm., 1996) and to the radiometric ages generated by Bogaard (Chap. 19, this volume) for this site.
\end{abstract}

\section{INTRODUCTION}

\section{Location and Setting}

Site 953 is located at $28^{\circ} 39.012^{\prime} \mathrm{N}, 15^{\circ} 8.670^{\prime} \mathrm{E}$ in the North Atlantic in $3577.8 \mathrm{~m}$ of water (Fig 1). It is situated $45 \mathrm{~km}$ northeast of Gran Canaria, $100 \mathrm{~km}$ west of Fuerteventura, and $100 \mathrm{~km}$ east of Tenerife. It is the most distally located site on the flanks of Gran Canaria and thus seems to have been spared some of the major slumped intervals and unconformities present at Sites 954, 955, and 956. High-resolution seismic survey data indicate no structural or other major complications at this site (Shipboard Scientific Party, 1995). Site 953 penetrated $1158.70 \mathrm{~m}$ of sediment and recovered an apparently complete stratigraphic section from the Pleistocene to the middle/lower Miocene (Zone CN3) as indicated by the nannofossil biostratigraphy. A fair paleomagnetic record for the Pliocene and a good paleomagnetic record for the Pleistocene and upper and middle Miocene was recovered down to 873.7 meters below sea floor (mbsf; Schmincke, Weaver, Firth, et al., 1995). Additional stratigraphic control was provided by ${ }^{40} \mathrm{Ar} /{ }^{39} \mathrm{Ar}$ dates from volcanic material present in Site 953 (Bogaard, Chap. 19, this volume). All in all, Site 953 is an excellent candidate for calcareous nannofossil biostratigraphy and for comparison with other geographic areas.

\section{Preparation Techniques and Examination}

Standard nannofossil smear-slide techniques were used to prepare samples. Unprocessed sediment was distributed on $50 \times 22 \mathrm{~mm} \# 1$ cover slips using wooden toothpicks. Samples were dried and mounted on glass slides using Norland Optical Adhesive 61 mounting medium.

Samples were examined at $900 \times$ and $1500 \times$ magnification, using a Nikon Optiphot2-pol microscope equipped with polarizing and phase-contrast optics. For each sample, a minimum of 350 individuals were counted at $1500 \times$ magnification. This ensures that species as rare as $1 \%$ will be counted with a $95 \%$ confidence level (Dennison and Hay, 1967). Fluctuations in nannofossil populations are revealed with this type of counting method. After counting, additional fields of view were scanned at both $1500 \times$ and $900 \times$ to ensure that rare, stratigraphically important species had been encountered.

${ }^{1}$ Weaver, P.P.E., Schmincke, H.-U., Firth, J.V., and Duffield, W. (Eds.), 1998. Proc. ODP, Sci. Results, 157: College Station, TX (Ocean Drilling Program).

${ }^{2} 6111$ Yarwell, Houston, TX 77096, U.S.A. (Present address: Exxon Exploration Company, P.O. Box 4778, Houston, TX 77210-4778) jsblevy@ hal-pc.org

${ }^{3}$ Challenger Division for Seafloor Processes, Southampton Oceanography Centre, Southampton, Hampshire SO14 3ZH, United Kingdom (Present address: Department of Geology and Geophysics, University of Western Australia, Nedlands WA 6907, Australia).

\section{Abundance and Preservation}

A qualitative estimate of the abundance of nannofossils relative to other particles on the slide was made for each sample. The categories used were very high $(\mathrm{VH})$, high $(\mathrm{H})$, moderate $(\mathrm{M})$, low $(\mathrm{L})$, very low (VL), and barren (B). A visual estimate of the preservational state of the nannofossils was also made for each sample. The categories used were good $(\mathrm{G})$, moderate $(\mathrm{M})$, and poor $(\mathrm{P})$. See full definitions in Schmincke, Weaver, Firth, et al. (1995).

\section{Nannoplankton Zonation}

The nannoplankton biostratigraphy of Site 953 is tied to the welldefined zonations of Bukry (1973), Okada and Bukry (1980), and Martini (1971). Also included in this biostratigraphic summary of Site 953 are more recently defined datum events occurring within the Okada and Bukry (1973) and the Martini (1971) zonations. Many of these events have been summarized in Young et al. (1994).

\section{Time Scale}

The revised integrated magnetobiochronologic time scale of Berggren et al. (1995) was used for this paper.

\section{BIOSTRATIGRAPHY OF SITE 953}

Pleistocene

The CN zones of Bukry (1973) and Okada and Bukry (1980), as well as the events outlined by Gartner (1977) and Raffi et al. (1993)

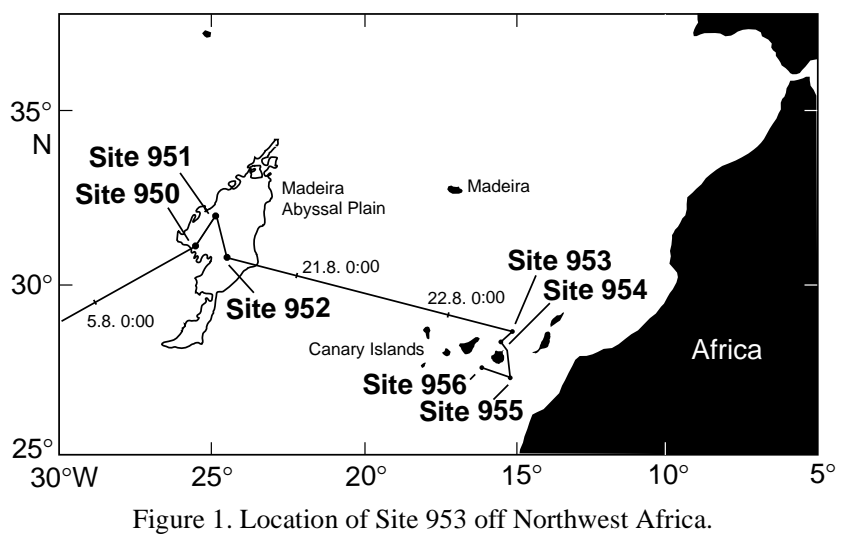


have been recognized in the Pleistocene section of Site 953. Table 1 summarizes the recorded Pleistocene nannofossil events and their positions at Site 953. Table 2 (on CD-ROM in the back pocket of this volume) shows the distribution of the recorded species at this site. Below is a discussion of some of the biostratigraphic events.

The change in dominance of Emiliania huxleyi and Gephyrocapsa caribbeanica within Zone CN15, and the lowest occurrence of $E$. huxleyi, which defines the CN15/CN14 boundary, were not determined at this site.

\section{Trends Within the Gephyrocapsa Complex}

The Gephyrocapsa complex has been subdivided into numerous species by many biostratigraphers over the years. In actual practice, it is very difficult to distinguish these species in the light microscope because of their small size and very similar appearance. For Site 953, the size classification method of Raffi et al. (1993) has been adopted to subdivide the Pleistocene stratigraphic record of the Gephyrocapsa. This size classification is as follows: (1) Gephyrocapsa $>5.5$ $\mu \mathrm{m}$ (large), (2) Gephyrocapsa $\geq 4.0 \mu \mathrm{m}$ (medium), and (3) those $<4.0$ $\mu \mathrm{m}$ (small). The usefulness of this size classification has been well documented in the sedimentary record of several oceans (Raffi et al., 1993; Sato and Takayama, 1992; Takayama, 1993; Young, 1994), and is again substantiated at Site 953 .

In addition to the morphometric subdivision of the Gephyrocapsa, one species has also been distinguished. This is the form with a bridge parallel to the short axis and is usually $\geq 4.0 \mu \mathrm{m}$. It is the $G$. "oceanica" of some biostratigraphers and the Gephyrocapsa omega of Bukry, 1973 (synonym G. parallela by Hay and Beaudy, 1973). In Figure 2, G. omega/parallela is plotted separately from the medium Gephyrocapsa, although it typically fits into this size range. The lowest occurrence of this species, in lower Chron C1r.1n (the Jaramillo), was used to identify the $\mathrm{CN} 14 \mathrm{a} / \mathrm{CN} 13 \mathrm{~b}$ boundary (Fig. 2). Many Gephyrocapsa events of the Pleistocene can be identified using the above described scheme.

The general trend during the late Pliocene to early Pleistocene from smaller to larger Gephyrocapsa is well expressed at Site 953. Subzones CN12d and CN13a in the late Pliocene are populated with the small Gephyrocapsa. Beginning in CN13b, the medium Gephyrocapsa enter the stratigraphic record and are then succeeded by the large Gephyrocapsa in mid-CN13b (Fig. 2). The end of the large Gephyrocapsa abundance peak, at $\sim 78.96 \mathrm{mbsf}$, signals the beginning of the "small Gephyrocapsa interval" of Gartner (1977). The small Gephyrocapsa interval ends with the entrance of the medium-sized $G$. omega/parallela at $\sim 64.73 \mathrm{mbsf}$.

Other trends within the data are a second small Gephyrocapsa interval in upper CN14a, above the highest occurrence of G. omega/ parallela (35.03 mbsf), and below an abundance peak in medium $G e$ phyrocapsa in CN14b (beginning at 25.02 mbsf; Fig. 2). This second small Gephyrocapsa interval is probably more subtle because the large Gephyrocapsa are not involved, only the medium ones. This second small Gephyrocapsa interval is succeeded by an abundance peak in the medium Gephyrocapsa, again followed by a peak in the large Gephyrocapsa in Zone CN15 (Fig. 2).

Although slightly different species criteria are used, a similar small Gephyrocapsa interval is noted in the Pacific by Firth and Isimingr-Kelso (1992; Fig. 2). They note that between roughly 0.80 and $0.60 \mathrm{Ma}$, there is an abundance interval of small Gephyrocapsa and an absence of medium Gephyrocapsa (their G. caribbeanica). At Site 953 , the interval is approximately between 0.7 and $0.54 \mathrm{Ma}$. Taking into consideration differences in time scales and differences in species criteria between these papers, the timing is similar enough to suggest that this is the same event.

\section{Reticulofenestra asanoi}

The highest occurrence of Reticulofenestra asanoi is relatively well defined at this site. The lowest occurrence of $R$. asanoi was difficult to determine. $R$. asanoi occurs in very low percentages below the Jaramillio event to the top of the Cobb Mountain event (Fig. 2).

\section{Helicosphaera sellii and Helicosphaera acuta}

The highest occurrence of Helicosphaera sellii is at $74.49 \mathrm{mbsf}$ (Sample 157-953A-9H-1, 39-40 cm) in the base of Chron C1r.2r (base of the Matuyama; Fig. 3). Raffi et al. (1993), showed that the extinction of $H$. sellii is time transgressive and that, in the North Atlantic (north of $18^{\circ}$ ), the extinction is relatively younger than in tropical regions. The extinction for $H$. selli at Site $953\left(28^{\circ} \mathrm{N}\right)$ is at $\sim 1.21$ Ma. This is fairly consistent with the results of Raffi et al. (1993), for

Table 1. Position of Pliocene-Pleistocene calcareous nannofossil events at Site 953.

\begin{tabular}{|c|c|c|c|c|}
\hline $\begin{array}{c}\text { Calcareous nannofossil } \\
\text { event }\end{array}$ & $\begin{array}{l}\text { Core, section, } \\
\text { interval }(\mathrm{cm})\end{array}$ & $\begin{array}{l}\text { Depth } \\
\text { (mbsf) }\end{array}$ & Chron & $\begin{array}{l}\text { Estimated age } \\
\qquad(\mathrm{Ma})^{*}\end{array}$ \\
\hline T Pseudoemiliania lacunosa & $3 \mathrm{H}-6,41.5 / 3 \mathrm{H}-6,48$ & $25.02-26.58$ & $\mathrm{C} 1 \mathrm{n}$ & $0.43-0.46$ \\
\hline T Reticulofenestra asanoi & $6 \mathrm{H}-2,59 / 6 \mathrm{H}-4,121$ & $46.32-47.70$ & C1r.1r & $0.83-0.85$ \\
\hline B common Reticulofenestra asanoi & $7 \mathrm{H}-5,11 / 7 \mathrm{H}-6,11$ & $61.21-62.70$ & C1r.1n & $1.03-1.05$ \\
\hline B Gephyrocapsa omega/parallela & $7 \mathrm{H}-\mathrm{CC} / 8 \mathrm{H}-1,42$ & $64.73-65.02$ & C1r.1n & 1.08 \\
\hline $\mathrm{T}$ Helicosphaera sellii & $8 \mathrm{H}-6,80 / 9 \mathrm{H}-1,40$ & $72.90-74.49$ & C1r.2r & $1.19-1.21$ \\
\hline B Reticulofenestra asanoi & $9 \mathrm{H}-2,10 / 9 \mathrm{H}-3,30$ & $75.70-77.40$ & C1r.2n & $1.23-1.25$ \\
\hline T large Gephyrocapsa $(>5.5 \mu \mathrm{m})$ abundance interval & $9 \mathrm{H}-4,36 / 9 \mathrm{H}-5,88$ & $78.96-80.98$ & C1r.2r & $1.27-1.30$ \\
\hline T Calcidiscus macintyrei & $10 \mathrm{H}-3,79-80 / 10 \mathrm{H}-4,107$ & $87.39-89.17$ & C1r.2r & $1.39-1.41$ \\
\hline B large Gephyrocapsa $(>5.5 \mu \mathrm{m})$ & $11 \mathrm{H}-2,69 / 11 \mathrm{H}-3,103$ & $95.29-95.30$ & C1r.2r & $1.49-1.52$ \\
\hline $\mathrm{T}$ common Calcidiscus macintyrei & $11 \mathrm{H}-5,127 / 11 \mathrm{H}-6,73$ & $100.37-101.33$ & $\mathrm{C} 1 \mathrm{r} .2 \mathrm{r}-\mathrm{C} 2 \mathrm{n}$ & $1.56-1.57$ \\
\hline B medium Gephyrocapsa $(\geq 4.0 \mu \mathrm{m})$ & $11 \mathrm{H}-5,127 / 11 \mathrm{H}-6,73$ & $100.37-101.33$ & $\mathrm{C} 1 \mathrm{r} \cdot 2 \mathrm{r}-\mathrm{C} 2 \mathrm{n}$ & $1.56-1.57$ \\
\hline T Discoaster brouweri & $15 \mathrm{H}-1,51 / 15 \mathrm{H}-2,75$ & $131.61-133.34$ & $\mathrm{C} 2 \mathrm{n}$ & $1.91-1.93$ \\
\hline \multicolumn{5}{|l|}{ T Discoaster triradiatus } \\
\hline T Discoaster pentaradiatus & $17 \mathrm{H}-6,43 / 17 \mathrm{H}-\mathrm{CC}$ & $158.03-159.61$ & $\mathrm{C} 2 \mathrm{r} \cdot 2 \mathrm{r}$ & Debris flow \\
\hline T Discoaster surculus & $17 \mathrm{H}-\mathrm{CC} / 18 \mathrm{H}-1,123$ & $159.61-160.83$ & $\mathrm{C} 2 \mathrm{r} .2 \mathrm{r}$ & Debris flow \\
\hline B Gephyrocapsa spp. small $(<4.0 \mu \mathrm{m})$ & $18 \mathrm{H}-3,10 / 18 \mathrm{H}-6,17$ & $162.70-167.89$ & $\mathrm{C} 2 \mathrm{r} \cdot 2 \mathrm{r}$ & $2.51-2.58$ \\
\hline T Discoaster asymmetricus & $18 \mathrm{H}-3,10 / 8 \mathrm{H}-6,17$ & $162.70-167.89$ & C2r.2r & $2.51-2.58$ \\
\hline T Discoaster tamalis & $19 \mathrm{H}-6,24 / 19 \mathrm{H}-\mathrm{CC}$ & $176.84-178.70$ & $\mathrm{C} 2 \mathrm{r} .2 \mathrm{r}-\mathrm{C} 2 \mathrm{An} .1 \mathrm{n}$ & $2.71-2.73$ \\
\hline T Sphenolithus spp. & $953 \mathrm{C}-8 \mathrm{R}-2,85 / 8 \mathrm{R}-1,51$ & $236.23-245.11$ & C2An.3n-C2Ar & $3.54-3.66$ \\
\hline $\begin{array}{l}\text { T "mid-Pliocene" small Gephyrocapsa spp. }(<4.0 \mu \mathrm{m}) \text { interval; } \\
\text { T Sphenolithus spp. }\end{array}$ & $8 \mathrm{R}-2,85 / 8 \mathrm{R}-3,95$ & $246.95-248.55$ & $\mathrm{C} 2 \mathrm{Ar}$ & $3.69-3.71$ \\
\hline T Reticulofenestra pseudoumbilica $(>7 \mu \mathrm{m})$ & $8 \mathrm{R}-4,17 / 8 \mathrm{R}-\mathrm{CC}$ & $249.27-249.40$ & $\mathrm{C} 2 \mathrm{Ar}$ & 3.72 \\
\hline B common Discoaster tamalis & $9 \mathrm{R}-4,7 / 10 \mathrm{R}-1,130$ & $258.67-265.00$ & $\mathrm{C} 3 \mathrm{n}$ & $4.02-4.17$ \\
\hline B "mid-Pliocene" small Gephyrocapsa spp. $(<4.0 \mu \mathrm{m})$ interval & $9 \mathrm{R}-4,7 / 10 \mathrm{R}-1,130$ & $258.67-265.00$ & $3 n$ & $4.02-4.17$ \\
\hline T Amaurolithus spp. & $10 \mathrm{R}-3,13 / 10 \mathrm{R}-\mathrm{CC}$ & $266.83-267.70$ & Probably C $3 n .2 n$ & $4.22-4.24$ \\
\hline
\end{tabular}

Notes: $\mathrm{T}=$ top or highest occurrence, and B = bottom or lowest occurrence. * = ages estimated by linear interpolation between paleomagnetic events (Schmincke, Weaver, Firth, et al., 1995; B. Herr, pers. comm., 1996), using age assignments from Berggren et al. (1995), and between paleomagnetic events and radiometric ages (Bogaard, Chap. 19, this volume), where available for Site $953 . /$ = the sample control within which the nannofossil event occurs. 


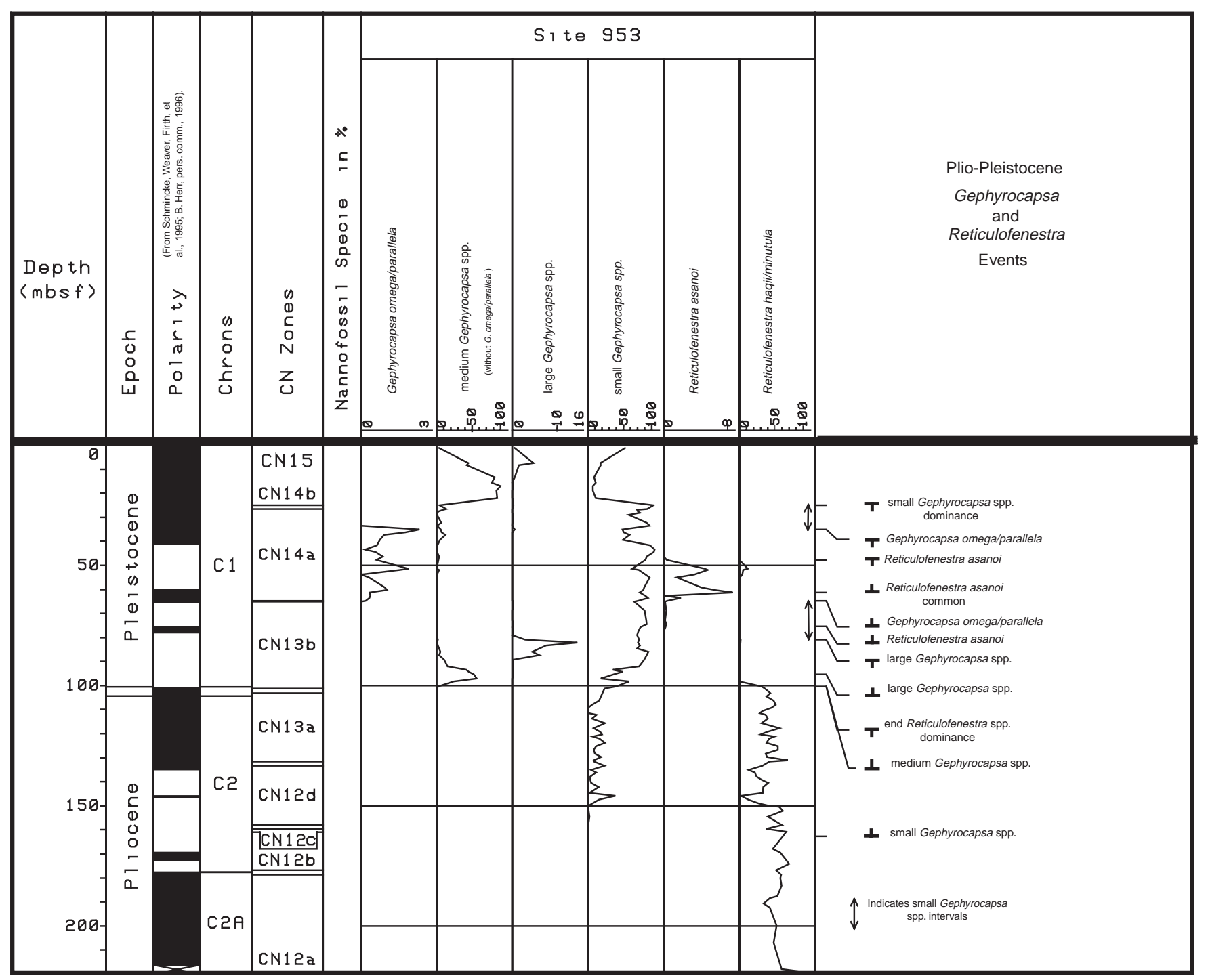

Figure 2. Gephyrocapsa and Reticulofenestra events in the Pliocene-Pleistocene at Site 953.

nearby North Atlantic Site $607\left(41 .^{\circ} 00^{\prime} \mathrm{N}, 32^{\circ} 57^{\prime} \mathrm{W}\right)$, where their estimated age was $1.241 \mathrm{Ma}$.

Another Helicosphaera species, Helicosphaera acuta (Theodoridis, 1984), may prove to be stratigraphically useful. This species occurs in Zones CN13 and CN12 at Site 953 (Fig. 3) and has also been reported at Deep Sea Drilling Program (DSDP) Site $397\left(26^{\circ} 50.7^{\prime} \mathrm{N}\right.$ $15^{\circ} 10.8^{\prime} \mathrm{W}$ ) in the North Atlantic in the same calcareous nannofossil zones by Theodoridis (1984). It is a fairly distinctive looking species, although it is difficult to get a representative photo of it (Theodoridis, 1984; plate 18, fig. 9). Although rare, it is present in the nannofossil assemblage from $82.10 \mathrm{mbsf}$ to $159.61 \mathrm{mbsf}$ at Site 953 , from Chrons C1r.2r to C2r.2r.

\section{Other Pleistocene Events}

Calcidiscus macintyrei is very rare from 89.17 (Sample 157953A-10H-4, $107 \mathrm{~cm}$ ) to 100.37-38 mbsf (Sample 157-953A-5, $127-128 \mathrm{~cm})$. At $101.33 \mathrm{mbsf}$, there is an major increase in abundance (Fig. 3). The last common occurrence of $C$. macintyrei is placed here at 101.33 mbsf.

The CN13b/CN13a boundary was originally defined by Bukry (1973) as the first occurrence of $G$. caribbeanica, a species difficult to recognize. Following the usage of Raffi and Flores (1995), we used the alternative definition of the lowest occurrence of the medium $G e$ phyrocapsa to recognize the $\mathrm{CN} 13 \mathrm{~b} / \mathrm{CN} 13 \mathrm{a}$ boundary. This event occurs just above Chron C2n, (upper Olduvai) at Site 953.

Percentage plots of the three Gephyrocapsa size classifications, of G. omega/parallela, Pseudoemiliania lacunosa, C. macintyrei, $R$. asanoi, Dictyococcites antarcticus, Dictyococcites productus, $H$. selli, and Reticulofenestra spp. (3-5 $\mu \mathrm{m}$ in size) are presented in Figures 2 and 3 . These figures graphically present the major fluctuations in flora and the major biostratigraphic events for the Pleistocene at this site.

The major change in dominance in the nannoflora $1.56 \mathrm{Ma}$ in the lower Pleistocene near the base of Subzone CN13b (100 mbsf) is well expressed at Site 953. Below 100 mbsf, Reticulofenestra species 3-5 $\mu \mathrm{m}$ in size are the dominant forms accompanied by $P$. lacunosa, $C$. macintyrei, and the $<4 \mu \mathrm{m}$ Gephyrocapsa species as subsidiary components. Above $100 \mathrm{mbsf}$, the dominant species are the Gephyrocap$s a$ species.

\section{Pliocene}

All the zones of Bukry (1973) and Okada and Bukry (1990) for the Pliocene can be recognized. Subzones CN10a, CN10b, and CN10c, however, cannot be distinguished because of the scarcity of 


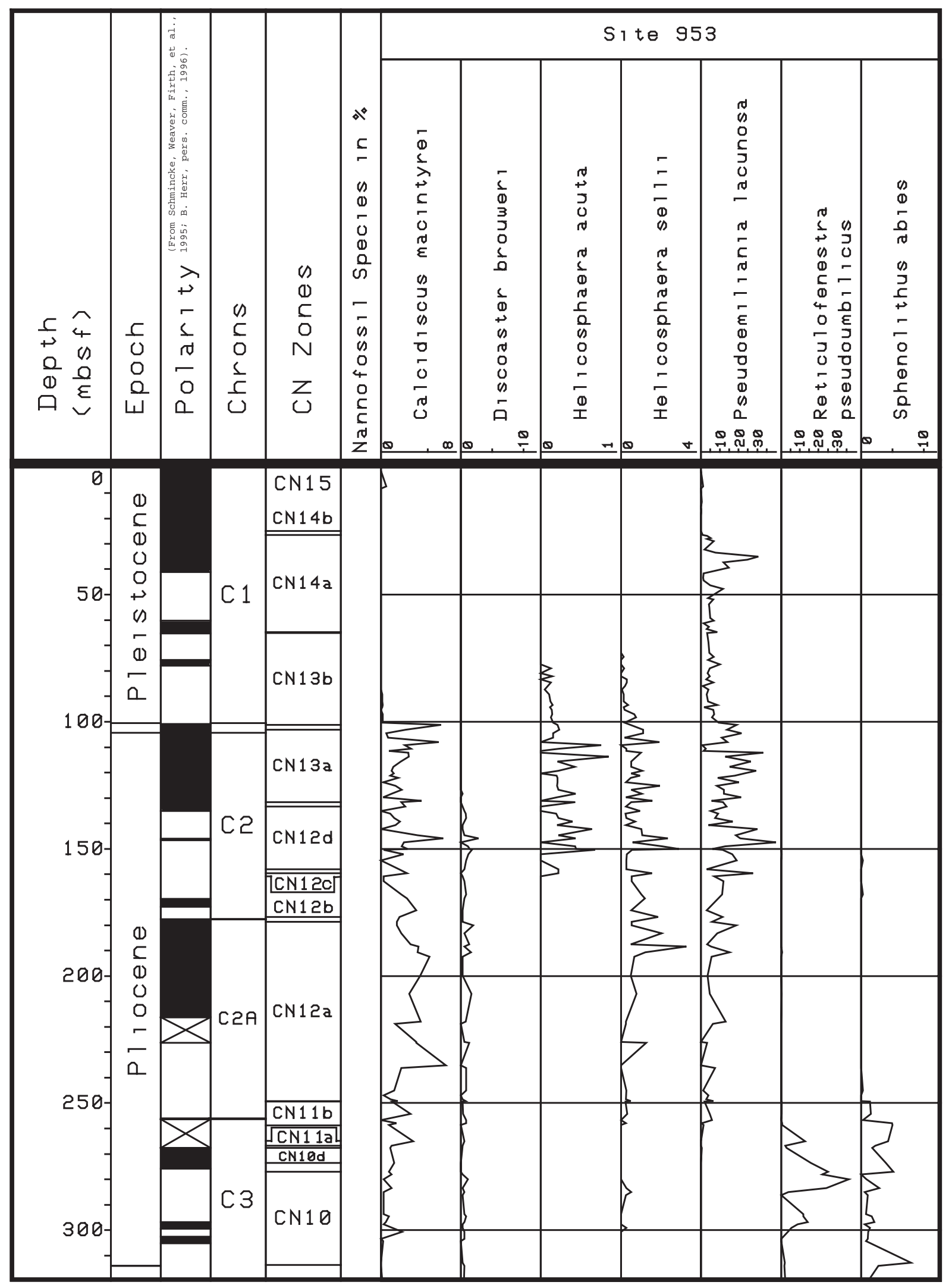

Figure 3. Additional Pliocene-Pleistocene datum events. 
ceratolid species. Unfortunately, the Pliocene paleomagnetic record at Site 953 has some intervals with uncertain polarity (Schmincke, Weaver, Firth, et al., 1995; B. Herr, pers. comm., 1996). Therefore, the nannofossils and paleomagnetic stratigraphy cannot be tied in those intervals. Table 1 summarizes the biostratigraphically significant nannofossil events in the Pliocene recognized at Site 953. Table 2 (on CD-ROM) shows the distribution of species at Site 953. Below is a discussion of some of these events.

\section{Zone CN12}

The marker for the CN13/CN12 boundary is Discoaster brouweri. The highest consistent occurrence of $D$. brouweri occurs with Discoaster triradiatus in Sample 157-953A-15H-2, $75 \mathrm{~cm}(133.34$ mbsf).

The highest occurrences of Discoaster pentaradiatus, Discoaster surculus, and Discoaster tamalis were identified at Site 953, and thus Subzones CN12c, CN12b, and CN12a were defined. It should be noted that the highest occurrence of $D$. surculus occurs within a debris flow from 159.60 to 160.56 mbsf. This may explain why $D$. surculus appears higher than expected. Occurring within $\mathrm{CN} 12 \mathrm{~b}$, below the highest occurrence of $D$. surculus, but above the highest occurrence of $D$. tamalis, was the lowest continuous occurrence of the $<4.0 \mu \mathrm{m}$ Gephyrocapsa species.

\section{Mid-Pliocene Gephyrocapsa Event}

With light microscope techniques (at $1500 \times$ magnification), Gephyrocapsa species are absent from the sedimentary record between 167.89 and $246.95 \mathrm{mbsf}$ at Site 953 . From 248.54 to $258.68 \mathrm{mbsf}$, however, straddling the boundary between Subzone CN12a and $\mathrm{CN} 11 \mathrm{~b}$, in the uppermost part of paleomagnetic Chron C2Ar, the Gilbert is an interval containing small $(<4.0 \mu \mathrm{m})$ Gephyrocapsa species. This mid-Pliocene event is plotted in Fig. 4. Typical Gephyrocapsa species are then absent again below $258.68 \mathrm{mbsf}$.

This discontinuous occurrence pattern was also observed at Sites 954 and 955 (Table 3). It is also evident in the data of Takayama and Sato (1987) from Leg 94 Sites 607, 608, 609, 610A, and 611C in the North Atlantic. Rio (1982) first noted this discontinuous occurrence pattern and abundance interval in Chron C2Ar, based on the analysis of four sites from the Equatorial Pacific, North Atlantic, and South Pacific. Site 953 fits the same pattern. This abundance interval appears to be a distinct event with regional distribution, and may be useful for biostratigraphy.

\section{Sphenolithus spp. Highest Occurrence}

Within lower CN12a, the highest occurrence of Sphenolithus spp. was noted at $245.11 \mathrm{mbsf}$ in uppermost Chron C2Ar (the Gilbert). As has been pointed out by many calcareous nannofossil biostratigraphers, this event typically occurs above the highest occurrence of Reticulofenestra pseudoumbilicus $(>7.0 \mu \mathrm{m})$.

\section{Zone CN11}

The CN12/CN11 boundary is indicated by the highest occurrence of R. pseudoumbilicus. Following the practice of Rio et al. (1990), $R$. pseudoumbilicus was divided into those forms 5-7 $\mu \mathrm{m}$ in size and those $>7 \mu \mathrm{m}$. If the $>7.0-\mu \mathrm{m}$ criteria is used, this Pliocene event is readily distinguished at Site 953. It occurs within Chron C2Ar, in the upper part of the Gilbert, as it does in other areas (Raffi and Flores, 1995; Rio et al., 1990; Backman and Shackleton, 1983). Subzone CN11b is indicated by the lowest occurrence of D. tamalis in Sample 157-953C-9R-4, 7-8 cm (258.67-258.68 mbsf).

\section{Zone CN10}

The CN11a/CN10 boundary, indicated by the highest occurrence of Amaurolithus species, occurs in Sample 157-953C-10-CC (267.70 mbsf). The lowest occurrence of Discoaster asymmetricus is the marker for the base of Subzone CN10d. At Site 953, D. asymmetricus occurs sporadically down to Sample 157-953C-11R-4, 12-13 cm (278.02-278.03 mbsf). The base of Subzone CN10d is tentatively placed here.

Subzones CN10c, CN10b, and CN10a were not distinguished because of the absence of marker species Ceratolithus rugosus and the near absence of Ceratolithus acutus at this site. C. acutus was observed in only one sample.

\section{Distribution of Coccolithus pelagicus in the Pliocene: Paleooceanographic Implications}

Two forms of Coccolithus pelagicus were distinguished within the Pleistocene and Pliocene: one was a larger form with a bar or bridge spanning the short axis of the placolith (" $C$. pelagicus with bridge" in Fig. 5), and the other was without a distinct bridge, the more or less "typical" C. pelagicus. The bridged form is restricted to the Quaternary and Pliocene at Site 953 (and Site 954), whereas the nonbridged form extends into the Miocene (and older).

Both the bridged form and the nonbridged form of $C$. pelagicus co-occur frequently in an interval from 217.97 to $159.61 \mathrm{mbsf}$ in upper Subzone CN12c to mid-Subzone CN12a (Fig. 5), from 3.28 to $2.36 \mathrm{Ma}$. Within this general increase, there are additional fluctuations. For example, at $\sim 188.23$ ( $2.87 \mathrm{Ma}$ ) and from 174.22 to 176.84 (2.67-2.71 Ma), there are peaks in abundances. If these forms represent the same cool water environment as they do today, which is not unreasonable for the late Pliocene, then this would suggest a cooler surface water mass at that time in this area relative to today.

It is fairly well documented that ice rafting began at $\sim 2.55-2.4 \mathrm{Ma}$ in the North Atlantic (Ruddiman et al., 1987). The increases in Florisphaera profunda (Fig. 5) beginning around that time at Site 953 probably reflects this change in surface water conditions. However, the distribution of $C$. pelagicus before 2.55 Ma would suggest that surface water cooling began earlier, $\sim 3.28 \mathrm{Ma}$ at this site. It is possible that the cooling may be related to a westward expansion of the cool water, upwelling zone of the Canary Current during this time. Perhaps the expansion of the Canary Current is a function of Northern Hemisphere glaciation.

Supporting the conclusion that the surface waters were cooler from $\sim 3.28$ to $2.36 \mathrm{Ma}$ is the distribution of Helicosphaera species. Based on modern day distribution (McIntyre and Bé, 1967), one of the environmental preferences of Helicosphaera species is that they prefer warmer water masses. There is an increase in the percentage of all Helicosphaera species beginning $~ 150 \mathrm{mbsf}$, just after the decrease in C. pelagicus forms (Fig. 5).

\section{Miocene}

All of the zones of Bukry (1973) and Okada and Bukry (1980) were identified in the Miocene. Additionally, more recently identified events within these zones of the Miocene (summary in Young et al., 1994) were noted wherever possible. Table 4 summarizes the biostratigraphically significant events in the Miocene for Site 953; Table 5 (on CD-ROM in the back pocket of this volume) shows the distribution of species at this site.

\section{Zone CN9}

Zone CN9 is defined by the total range of Discoaster quinqueramus and Discoaster berggrenii. The highest occurrence of D. quinqueramus was found in Sample 157-953C-16R-2, $132 \mathrm{~cm}$, at 324.42 mbsf in Chron C3Ar. It is absent from 325.43 to 336.33 mbsf (Samples $157-953 \mathrm{C}-16 \mathrm{R}-3,84 \mathrm{~cm}$, to $17 \mathrm{R}-4,73-74 \mathrm{~cm}$ ), probably because of the poor preservation affecting the discoasters in that interval. It reappears in Sample 157-953C-17R-5, 144 cm (338.54 mbsf) 


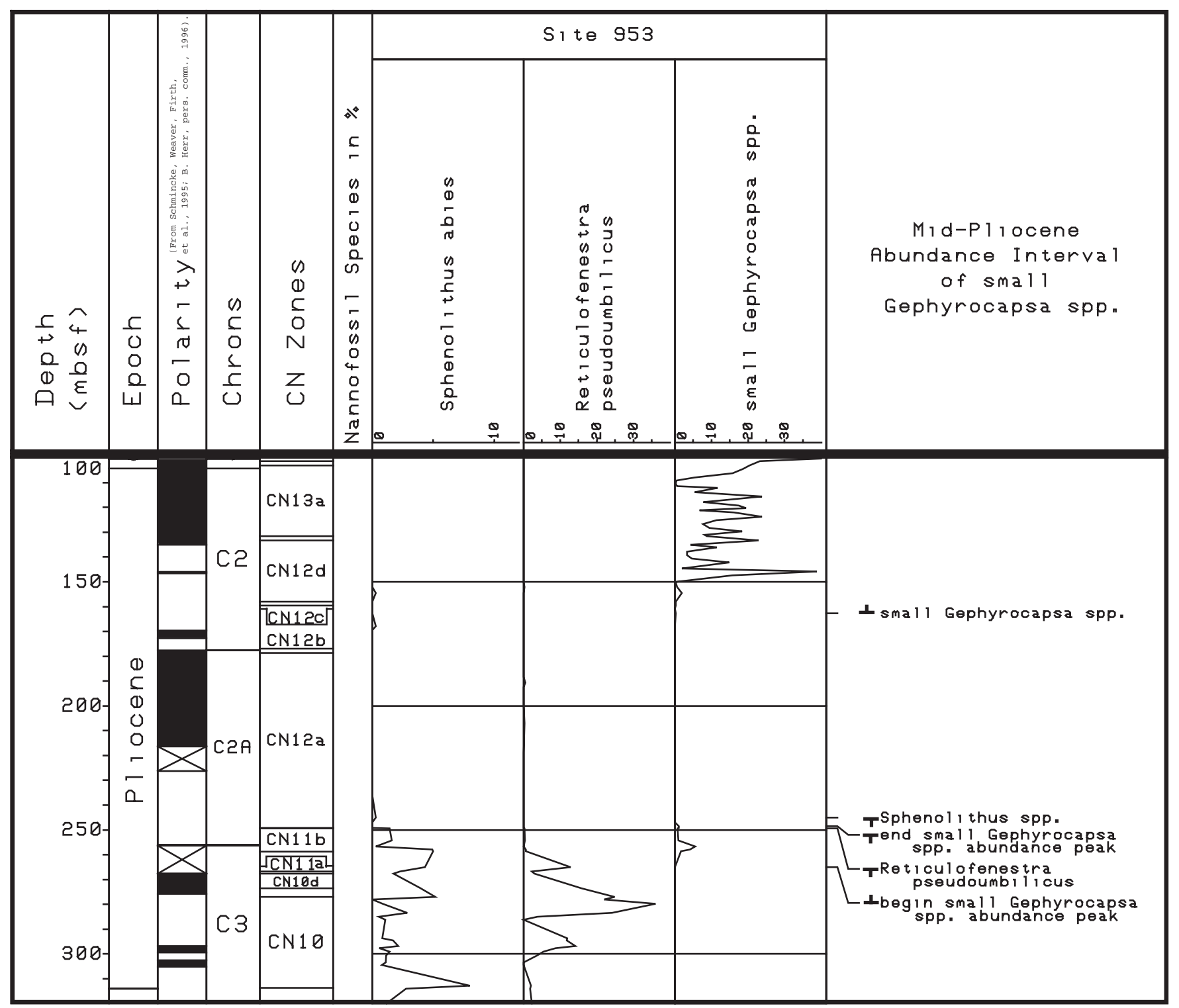

Figure 4. Mid-Pliocene abundance interval of small $(<4 \mu \mathrm{m})$ Gephyrocapsa plotted vs. Sphenolithus spp. and the large Reticulofenestra pseudoumbilicus $(>7$ $\mu \mathrm{m})$.

and is joined by the highest occurrence of $D$. berggrenii in Sample 157-953C-18R-2, $98 \mathrm{~cm}$, at 343.08 mbsf.

The poor preservation in the 325-336 mbsf interval may also have influenced the distribution of Triquetrorhabdulus rugosus. The highest occurrence of T. rugosus at Site 953 is at $340.96 \mathrm{mbsf}$ (Sample 157-953C-18R-1, $36 \mathrm{~cm}$ ), which is below the highest occurrence of A. amplificus in Chron C3An. Other published occurrences of T. rugosus (Rio et al., 1990) are above the lowest occurrence of A. amplificus.

Subzones CN9a and CN9b can be recognized at Site 953 based on the first occurrence of Amaurolithus primus. The lowest occurrence of A. primus is in Sample 157-953C-21R-5, $101 \mathrm{~cm}$, at $376.51 \mathrm{mbsf}$ in Chron $\mathrm{C} 3 \mathrm{Br}$ defining the CN9b/CN9a boundary.

The highest occurrence (Sample 157-953C-17R-5, $144 \mathrm{~cm}$, $338.54 \mathrm{mbsf}$ ) of $A$. amplificus occurs as a distinct event in the upper part of Subzone CN9b at Site 953, with an estimated age of $5.9 \mathrm{Ma}$, which is in good agreement with other areas (Rio et al., 1990; Raffi and Flores, 1995). The lowest occurrence of A. amplificus is within a slumped interval between 350.72 and 361.89 mbsf.
The lowest occurrence of $A$. delicatus occurs from 373.90 to $373.91 \mathrm{mbsf}$ (Sample 157-953C-21R-3, 140-141 cm) in lower subzone CN9b, Chron C3Br, stratigraphically above the highest occurrence of Discoaster loeblichii at 374.34-374.35 mbsf (Sample 157953C-21R, 34-35 cm).

Other events that occur within Subzone CN9b are the highest occurrence of Cryptococcolithus takayamae at $344.61 \mathrm{mbsf}$ and the highest occurrence of $C$. pliopelagicus at $351.63 \mathrm{mbsf}$, both in a slumped interval in undifferentiated Chron C3An. In comparison to Site 608 (Gartner, 1992), the highest occurrence of C. takayamae is lower at Site 953 than at Site 608. The highest occurrence of $C$. pliopelagicus is similar to that at Site 608 .

The highest occurrence of Minylitha convallis is at 384.00384.01 mbsf (Sample 157-953C-22R-4, 40-41 cm) in Subzone CN9a, upper Chron C4n.2n. This stratigraphic position is in good agreement with that of Gartner (1992) for Site 608 in the North Atlantic and with Rio et al. (1990) for the Indian Ocean.

The first occurrence of $D$. berggrenii was used to define the CN9a/CN8 boundary (Bukry, 1973). This event occurs at Site 953 at 
Table 3. Distribution of small Gephyrocapsa spp. $(<4.0 \mu \mathrm{m})$ in "midPliocene" for Sites 953, 954, and 955.

\begin{tabular}{|c|c|c|c|}
\hline $\begin{array}{l}\text { Core, section, } \\
\text { interval }(\mathrm{cm})\end{array}$ & $\begin{array}{l}\text { Depth } \\
\text { (mbsf) }\end{array}$ & $\begin{array}{l}\text { Subzone } \\
\text { or zone }\end{array}$ & $\begin{array}{c}\text { Small } \\
\text { Gephyrocapsas? }\end{array}$ \\
\hline $\begin{array}{l}\text { 157-953C- } \\
\text { 7R-1, 13 } \\
\text { 7R-1, 123 } \\
\text { 8R-1, 51 } \\
8 \mathrm{R}-2,85-86 \\
\text { 8R-3, 94-95 } \\
8 \mathrm{R}-4,17 \\
\text { 8R-CC } \\
\text { 9R-1, } 8 \\
\text { 9R-2, 112-113 } \\
\text { 9R-3, 81 } \\
\text { 9R-4, 7-8 } \\
\text { 10R-1, 130 } \\
\text { 10R-3, 13-14 } \\
\text { 10R-CC } \\
\text { 11R-1, 15 } \\
\text { 11R-3, 57 }\end{array}$ & $\begin{array}{l}235.13 \\
236.23 \\
245.11 \\
246.95-.96 \\
248.54-.55 \\
249.27 \\
249.40 \\
254.18 \\
256.72-.73 \\
257.91 \\
258.67-68 \\
265.00 \\
266.83-.84 \\
267.70 \\
273.55 \\
276.97\end{array}$ & $\begin{array}{l}\text { CN12a } \\
\text { CN12a } \\
\text { CN12a } \\
\text { CN12a } \\
\text { CN12a } \\
\text { CN12a } \\
\text { CN11b } \\
\text { CN11b } \\
\text { CN11b } \\
\text { CN11b } \\
\text { CN11b } \\
\text { CN11a } \\
\text { CN11a } \\
\text { CN10d } \\
\text { CN10d } \\
\text { CN10d }\end{array}$ & $\begin{array}{l}\text { No } \\
\text { No } \\
\text { No } \\
\text { No } \\
\text { No } \\
\text { Yes } \\
\text { Yes } \\
\text { Yes } \\
\text { Yes } \\
\text { Yes } \\
\text { Yes } \\
\text { Yes } \\
\text { Yes } \\
\text { No } \\
\text { No } \\
\text { No }\end{array}$ \\
\hline $\begin{array}{l}\text { 157-954B } \\
\text { 5R-2, 89 } \\
5 \mathrm{R}-4,24 \\
6 \mathrm{R}-3,12 \\
\text { 7R-4, 55 } \\
\text { 8R-2, 105 } \\
\text { 9R-CC } \\
11 \mathrm{R}-3,6 \\
\text { 12R-1, 89.5 } \\
\text { 12R-CC } \\
\text { 13R-1 71 } \\
\text { 14R-CC, } 5.5\end{array}$ & $\begin{array}{l}121.69 \\
124.04 \\
132.12 \\
143.65 \\
150.55 \\
158.00 \\
179.97 \\
187.80 \\
190.18 \\
197.21 \\
206.26\end{array}$ & $\begin{array}{l}\text { CN12a } \\
\text { CN12a } \\
\text { CN12a } \\
\text { CN12a } \\
\text { CN12a } \\
\text { CN12a } \\
\text { CN12a } \\
\text { CN12a } \\
\text { CN11b } \\
\text { CN11b } \\
\text { CN11a }\end{array}$ & $\begin{array}{l}\text { No } \\
\text { No } \\
\text { No } \\
\text { No } \\
\text { No } \\
\text { No } \\
\text { No } \\
\text { No } \\
\text { Yes } \\
\text { No } \\
\text { No }\end{array}$ \\
\hline $\begin{array}{l}157-955 \mathrm{~A}- \\
18 \mathrm{H}-\mathrm{CC}, 10 \\
19 \mathrm{X}-7,27 \\
20 \mathrm{X}-6,40 \\
21 \mathrm{X}-2,40 \\
22 \mathrm{X}-6,11 \\
23 \mathrm{X}-3,89 \\
24 \mathrm{X}-1,27 \\
25 \mathrm{X}-1,12 \\
25 \mathrm{X}-7,18 \\
26 \mathrm{X}-2,40 \\
27 \mathrm{X}-4,26 \\
28 \mathrm{X}-5,34\end{array}$ & $\begin{array}{l}168.52 \\
178.17 \\
184.35 \\
187.90 \\
203.11 \\
208.99 \\
214.87 \\
224.42 \\
233.40 \\
235.90 \\
248.36 \\
259.64\end{array}$ & $\begin{array}{l}\text { CN12a } \\
\text { CN12a } \\
\text { CN12a } \\
\text { CN12a } \\
\text { CN12a } \\
\text { CN11 } \\
\text { CN11 } \\
\text { CN11 } \\
\text { CN11 } \\
\text { CN11 } \\
\text { CN10 } \\
\text { CN10 }\end{array}$ & $\begin{array}{l}\text { No } \\
\text { No } \\
\text { No } \\
\text { No } \\
\text { Yes } \\
\text { Yes } \\
\text { Yes } \\
\text { Yes } \\
\text { Yes } \\
\text { Yes } \\
\text { No } \\
\text { No }\end{array}$ \\
\hline
\end{tabular}

401.38-401.40 mbsf (Sample 157-953C-24R-3, 28-30 cm) at the Chron C4r.1n/C4r.2r boundary.

\section{Zone CN8}

Bukry (1973) divided Zone CN8 into an upper Subzone CN8b, which contained D. loeblichii and Discoaster neorectus, and a lower Subzone CN8a without these markers. The lowest occurrence of $D$. loeblichii is in Sample 157-953C-27R-1, $34 \mathrm{~cm}$, (427.34 mbsf), thus permitting recognition of $\mathrm{CN} 8 \mathrm{~b}$ and $\mathrm{CN} 8 \mathrm{a}$. The other marker for the base of Zone CN8b, D. neorectus, was not seen at Site 953.

The CN8/CN7 boundary was indicated by the highest occurrence of Discoaster hamatus (467.26 mbsf; C4Ar.2r). Other events within Subzone CN8a were the highest occurrence of $D$. neohamatus (442.21 mbsf) and Discoaster bollii (443.00 mbsf), both within Chron C4Ar.1n (which seems a little high relative to other sites).

Small Reticulofenestra Zone: Absence Interval of Reticulofenestra pseudoumbilicus

Following the work of Rio et al. (1990), and Young (1990), we divided the Reticulofenestra complex into several morphotypes based on size. The groups distinguished were as follows: $R$. pseudoumbilicus, $>7 \mu \mathrm{m}$; R. pseudoumbilicus, 5-7 $\mu \mathrm{m}$; Reticulofenestra species, $3-$ $5 \mu \mathrm{m}$ (predominately $R$. minutula and $R$. haqii); and Reticulofenestra species, $<3 \mu \mathrm{m}$ in size. In addition, reticulofenestrid forms with a closed center were called $D$. productus (smaller forms) and $D$. antarcticus (larger forms).
The "small Reticulofenestra interval" or the R. pseudoumbilicus absence interval (Young, 1990) can be identified by the essentially simultaneous last common abundances of the $>7 \mu \mathrm{m},>5-7 \mu \mathrm{m}$, and the 5-3 $\mu \mathrm{m}$ Reticulofenestra. At Site 953, this occurs within lower CN8b, in the top of C4A (Fig. 6). The absence interval of the larger Reticulofenestra is characterized by abundance peaks of the $<3 \mu \mathrm{m}$ Reticulofenestra and of $D$. productus (abundance peaks $\mathrm{C} 1, \mathrm{C} 2$, and $\mathrm{C} 3$ in Fig. 6). The abundance peak in D. productus spans the upper C4A to C4n.2n interval. A similar abundance peak is seen at Site 608 (Gartner, 1992; fig. 5).

The larger Reticulofenestra reenter the stratigraphic record sporadically and, at different times, for the different size categories. The absence interval of the 3-5 $\mu \mathrm{m}$ Reticulofenestra is the shortest and best defined, ranging only from Chron $4 \mathrm{r} .2 \mathrm{r}(404.15 \mathrm{~m})$ to the top of C4An (422.87 mbsf) within CN8b. The absence intervals of the 5-7 $\mu \mathrm{m}$ and $>7 \mu \mathrm{m}$ Reticulofenestra are longer, and their reentrance into the stratigraphic record is less clearly defined than the 3-5 $\mu \mathrm{m}$ forms. The 5-7 $\mu \mathrm{m}$ Reticulofenestra do not become consistently present again until $\sim 384$ mbsf in upper CN9a, Chron 4n.2n. This reentrance is before the reentrance of the $>7 \mu \mathrm{m}$ forms, which do not become consistently present again until $\sim 350.00 \mathrm{mbsf}$ (Fig. 6).

Below 430 mbsf (Chron C4An), the $<3 \mu \mathrm{m}$ Reticulofenestra species are essentially absent from the stratigraphic record of the upper and middle Miocene at Site 953. This pattern of almost total absence of $<3 \mu \mathrm{m}$ Reticulofenestra species in the late and middle Miocene is also present in the data of Gartner (1992) for Site 608.

Abundance Peak of Small Sphenolithus Species

Within lower CN9 and most of $\mathrm{CN} 8$, there is a distinct abundance increase in small Sphenolithus species (curve F in Fig. 6) which, in places, overlaps with the abundance peaks in $<3 \mu \mathrm{m}$ Reticulofenestra and $D$. productus. Takayama (1993) noted this increase in small Sphenolithus species (which he called Sphenolithus abies) in the sediments of the Ontong Java Plateau in Leg 130 in upper NN10. At Site 953, all very small Sphenolithus species were grouped in Sphenolithus spp., whereas S. abies, Sphenolithus compactus, Sphenolithus conicus, Sphenolithus moriformis and, of course, Sphenolithus heteromorphus, were distinguished.

\section{Zone CN7}

Zone CN7 is defined by the total range of $D$. hamatus. The highest occurrence of D. hamatus is at $459.87 \mathrm{mbsf}$ (Sample 157-953C-30R$3,97 \mathrm{~cm}$ ) within Chron C4Ar.2r. This is in good agreement with other areas. Its lowest occurrence is at 516.07 mbsf in Chron C5n.2n, with an estimated age of 10.2 m.y., which is quite young relative to other areas. Other events within Zone CN7 are the lowest occurrence of $M$. convallis (485.69 mbsf at the C $5 \mathrm{n} .1 \mathrm{n} / \mathrm{C} 4 \mathrm{Ar}$ boundary), highest occurrence of Catinaster coalitus (in the same sample), and the lowest occurrence of D. neohamatus (488.22 mbsf).

\section{Zone CN6}

The first occurrence (FO) of $D$. hamatus defines the upper boundary of this zone, and the FO of $C$. coalitus defines the lower boundary of Zone CN6. C. coalitus was present fairly consistently from 485.69 mbsf (uppermost C5n.1n) to 539.19-539.21 mbsf (C5n.2n), thus permitting definition of Zone CN6. Catinaster calyculus is also present in Zone CN7 through upper Zone CN6 but is very rare and irregularly present.

\section{Highest Occurrence of Coccolithus miopelagicus}

Coccolithus miopelagicus shows a discontinuous distribution pattern at Site 953. It is present in several samples in CN7 (from 505.61 to $506.61 \mathrm{mbsf}$ ), spanning lowermost Chron C5n.1n to uppermost C5n.2n. It is then absent until Zone CN5, where it is consistently present from 547.29-.31 mbsf, Chron C5n.2n/C5r.1r, to the base of 


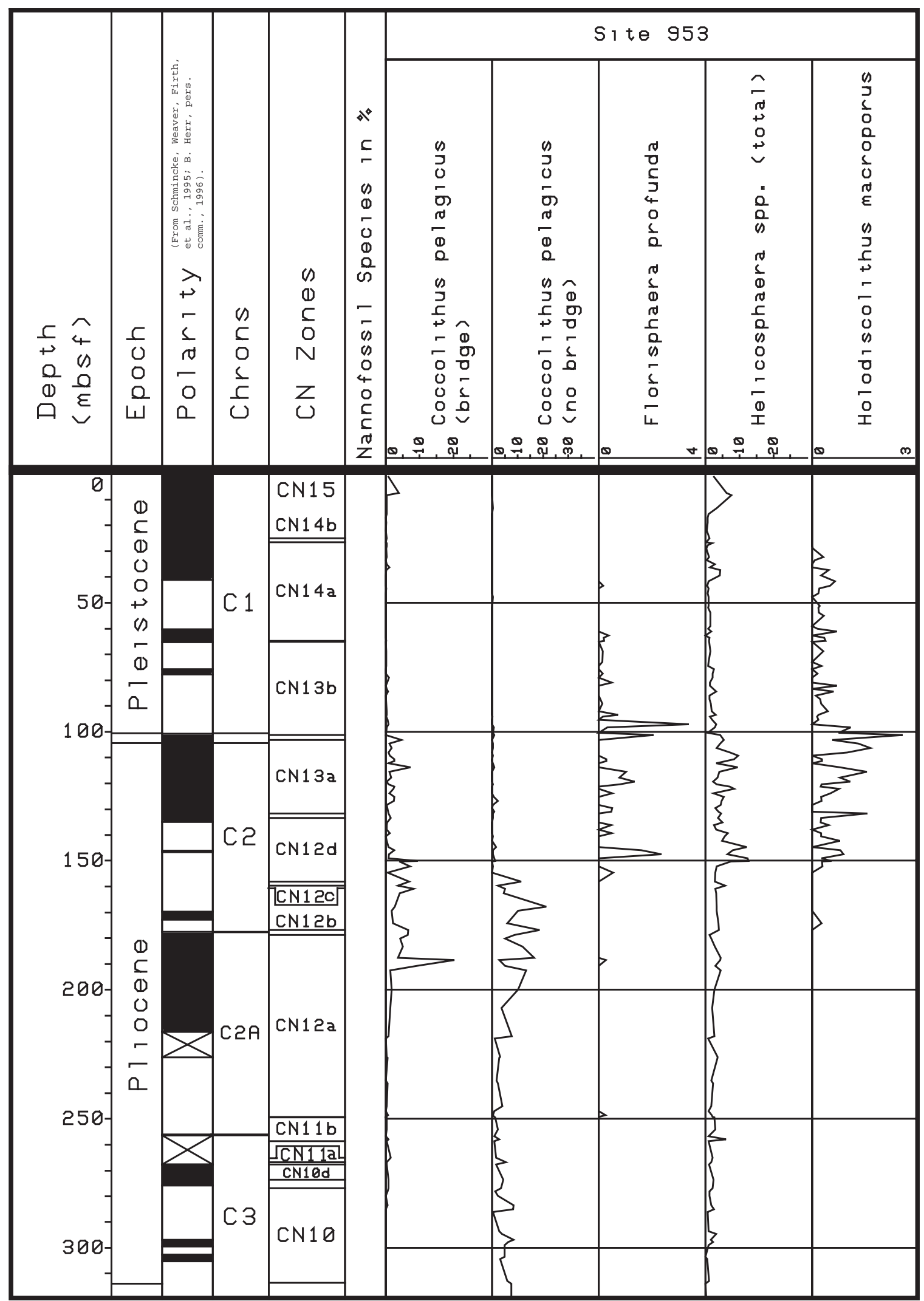

Figure 5. Percentage plots of Coccolithus pelagicus (with and without bridge) and all Helicosphaera species (as a total). 
Table 4. Position of Miocene calcareous nannofossil events at Site 953.

\begin{tabular}{|c|c|c|c|c|}
\hline $\begin{array}{c}\text { Calcareous nannofossil } \\
\text { event }\end{array}$ & Core, section, interval $(\mathrm{cm})$ & Depth (mbsf) & Chron & $\begin{array}{l}\text { Estimated age } \\
(\mathrm{Ma})^{*}\end{array}$ \\
\hline T Discoaster quinqueramus & $15 \mathrm{R}-2,38 / 16 \mathrm{R}-2,132$ & $313.98-324.42$ & $\mathrm{C} 3 \mathrm{r}$ & $5.4-5.6$ \\
\hline T Amaurolithus amplificus & $17 \mathrm{R}-4,73 / 17 \mathrm{R}-5,144$ & 336.33-338.54 & - & 5.9 \\
\hline B Amaurolithus amplificus & $19 \mathrm{R}-1,48 / 19 \mathrm{R}-1,143$ & $350.68-351.63$ & - & Slumped interval \\
\hline $\mathrm{T}$ Amaurolithus primus & $19 \mathrm{R}-1,48 / 19 \mathrm{R}-1,143$ & $350.68-351.63$ & - & Slumped interval \\
\hline $\mathrm{T}$ Coccolithus pliopelagicus & 19R-1, 48/19R-1, 143 & $350.68-351.63$ & - & Slumped interval \\
\hline B Amaurolithus delicatus & $21 \mathrm{R}-3,140 / 21 \mathrm{R}-4,35$ & $373.90-374.35$ & $\mathrm{C} 3 \mathrm{Br}$ & 7.1 \\
\hline T Discoaster loblichii & $21 \mathrm{R}-3,140 / 21 \mathrm{R}-4,35$ & $373.90-374.35$ & $\mathrm{C} 3 \mathrm{Br}$ & 7.1 \\
\hline В Amaurolithus primus & $21 \mathrm{R}-5,101 / 22 \mathrm{R}-1,63$ & $376.51-379.73$ & $\mathrm{C} 3 \mathrm{Br}$ & $7.2-7.4$ \\
\hline $\mathrm{T}$ Calcidiscus tropicus & $21 \mathrm{R}-5,101 / 22 \mathrm{R}-1,63$ & $376.51-379.73$ & $\mathrm{C} 3 \mathrm{Br}$ & $7.2-7.4$ \\
\hline $\mathrm{T}$ Minylitha convallis & $22 \mathrm{R}-4,40 / 22 \mathrm{R}-5,18$ & $384.00-385.28$ & C $4 n .2 n$ & $7.7-7.8$ \\
\hline B Discoaster berggrenii & $24 \mathrm{R}-3,28 / 24 \mathrm{R}-4,60$ & $401.38-403.20$ & $\mathrm{C} 4 \mathrm{r} .1 \mathrm{n}-\mathrm{C} 4 \mathrm{r} .2 \mathrm{r}$ & 8.3 \\
\hline $\begin{array}{l}\text { T common Reticulofenestra spp. } \\
(>7,5-7,3-5 \mu \mathrm{m}) ; \\
\text { beginning of "large" Reticulofenestra } \\
\text { absence interval }\end{array}$ & $26 \mathrm{R}-2,28 / 26 \mathrm{R}-4,107$ & $419.08-422.87$ & C4An & $8.7-8.8$ \\
\hline B Discoaster loeblichii & 27R-1, 34/27R-2, 95 & $427.34-429.45$ & C4An & $8.8-8.9$ \\
\hline T Discoaster neohamatus & $28 \mathrm{R}-3,22 / 28 \mathrm{R}-4,113$ & $439.82-442.23$ & 4Ar.1r & 9.2 \\
\hline T Discoaster bollii & $28 \mathrm{R}-4,111 / 28 \mathrm{R}-5,40$ & $442.21-443.00$ & C4Ar.1n & 9.2 \\
\hline B Discoaster pentaradiatus & $30 \mathrm{R}-2,30 / 30 \mathrm{R}-3,98$ & $457.70-459.88$ & C4Ar.2r & $9.3-9.4$ \\
\hline T Discoaster hamatus & $30 \mathrm{R}-3,97 / 31 \mathrm{R}-2,25.5$ & $459.87-467.26$ & C4Ar.2r & $9.4-9.5$ \\
\hline $\mathrm{T}$ Catinaster coalitus & $32 \mathrm{R}-4,51 / 33 \mathrm{R}-1,78.5$ & $480.21-485.69$ & $4 \mathrm{Ar} .3 \mathrm{r}$ & $9.7-9.8$ \\
\hline B Minylitha convallis & $33 \mathrm{R}-1,78.5 / 33 \mathrm{R}-2,103$ & $485.69-487.43$ & C5n.1n & $9.7-9.8$ \\
\hline B Discoaster neohamatus & $33 \mathrm{R}-3,32 / 33 \mathrm{R}-4,63$ & $488.22-490.03$ & C $5 n .1 n$ & 9.8 \\
\hline $\mathrm{T}$ Coccolithus miopelagicus & $34 \mathrm{R}-5,50 / 35 \mathrm{R}-2,15$ & $500.62-505.61$ & C $5 n \cdot 1 n-C 5 n .2 n$ & 9.9 \\
\hline B Discoaster hamatus & $36 \mathrm{R}-2,77 / 36 \mathrm{R}-4,41$ & $516.07-518.50$ & C $5 n .2 n$ & 10.2 \\
\hline B Discoaster coalitus & $38 \mathrm{R}-5,56 / 39 \mathrm{R}-1,96$ & $539.19-543.76$ & C $5 n .2 n$ & $10.8-10.9$ \\
\hline $\mathrm{T}$ common Coccolithus miopelagicus & $39 \mathrm{R}-2,94 / 39 \mathrm{R}-4,49$ & $545.12-547.31$ & C5n.2n-C5r.1r & $10.9-10.98$ \\
\hline T common Discoaster kugleri & $42 \mathrm{R}-1,44 / 43 \mathrm{R}-1,48$ & $571.84-581.48$ & C5r.2r & 11.3-11.4 \\
\hline Т Cyclicargolithus floridanus & $46 \mathrm{R}-1,10 / 46 \mathrm{R}-2,14$ & $610.1-611.03$ & - & Slumped interval \\
\hline B Discoaster kugleri & $47 \mathrm{R}-4,32 / 48 \mathrm{R}-2,45$ & $623.35-630.68$ & C5An.1n-C5An.1r & 12.1 \\
\hline $\mathrm{T}$ Coronocyclus nitescens & $49 \mathrm{R}-6,77 / 50 \mathrm{R}-1,52$ & $646.35-649.02$ & C5An.2n & $12.2-12.3$ \\
\hline $\mathrm{T}$ Calcidiscus premacintyrei & $50 \mathrm{R}-3,128 / 51 \mathrm{R}-1,89$ & $652.67-658.99$ & C $5 \mathrm{An} .2 \mathrm{n}$ & $12.3-12.4$ \\
\hline B Calcidiscus macintyrei & $50 \mathrm{R}-3,128 / 51 \mathrm{R}-1,89$ & $652.67-658.99$ & C5An.2n & $12.3-12.4$ \\
\hline T Sphenolithus heteromorphus & $63 \mathrm{R}-1,1 / 64 \mathrm{R}-2,8$ & $773.11-784.34$ & $\mathrm{C} 5 \mathrm{ABr}$ & $\begin{array}{c}13.5-13.6^{* * *} \\
13.44^{\dagger}\end{array}$ \\
\hline T Discoaster petaliformis & $65 \mathrm{R}-4,108 / 65 \mathrm{R}-6,11$ & 797.27-799.10 & $\mathrm{C} 5 \mathrm{ACn}$ & 13.7 \\
\hline B Dictyococcites productus/antarcticus & 73R-5, 109/74R-1, 2 & $876.56-879.42$ & - & \\
\hline T Helicosphaera ampliaperta & $83 \mathrm{R}-2,27.5 / 83 \mathrm{R}-2,83$ & $967.61-968.16$ & - & \\
\hline
\end{tabular}

Notes: $*$ = ages are estimated by linear interpolation between paleomagnetic events (from Schmincke, Weaver, Firth, et al., 1995; B. Herr, pers. comm., 1996) using age assignments from Berggren et al. (1995) and between paleomagnetic events and radiometric ages (from Bogaard, Chap. 19, this volume), where available for Site 953. T = top or highest occurrence and $\mathrm{B}=$ bottom or lowest occurrence. $\dagger=$ age estimate using only paleomagnetic events for control. $-=$ no data, and $/=$ the sample control within which the nannofossil event occurs. $* *=$ age interpolated between the radiometric date of $13.44 \mathrm{Ma}$ at $784.76 \mathrm{mbsf}$ and the paleomagnetic date of 13.25 for Chron $\mathrm{C} 5 \mathrm{ABn}$ termination at $731.8-732.1$ mbsf.

the site. The occurrences in $\mathrm{CN} 7$ were considered reworked, and the occurrences in Chron C5n.2n/C5r.1r, Zone CN5, were considered the highest true occurrences.

\section{Zone CN5}

The top of Zone CN5 is defined by the first occurrence of $C$. coalitus, and the bottom of Zone CN5 is defined by the last occurrence of $S$. heteromorphus. Both events were easily recognized at Site 953. There are several events within Zone CN5 that were used to subdivide this zone

The highest occurrence of Calcidiscus premacintyrei is at least as high as 668.47-668.48 mbsf (Sample 157-953C-52R-1, 77.78 cm) in Chron C5Ar.1r and may be higher. C. praemacintyreii was easily found in this sample, which suggests that its last occurrence is probably higher. The next highest sample examined, however, was Sample $157-953 \mathrm{C}-51 \mathrm{R}-6,10 \mathrm{~cm}$, at $664.85 \mathrm{mbsf}$, which had poor preservation. In the next higher sample (157-953C-51R-1, $89 \mathrm{~cm}$, at 658.99 mbsf, in Chron 5An.2n), a just slightly oval specimen was found (called Calcidiscus aff. macintyrei). This suggests that the last evolutionary occurrence is between 658.99 mbsf in lower Chron 5An.2n (Sample 157-953C-51R-1, $89 \mathrm{~cm}$ ) and 668.47-668.48 mbsf in uppermost Chron C5Ar.1r (Sample 157-953C-52R-1, 77-78 cm). At Site 608 (Gartner, 1992), the highest occurrence of C. premacintyrei was in an undifferentiated normal section of Chron 5A, thus suggesting that the lowermost Chron $5 \mathrm{An} .2 \mathrm{n}$ is the more likely position for this event.

T. rugosus was found consistently down to $678.11 \mathrm{mbsf}$ (Sample 157-953C-53R-1, $71 \mathrm{~cm}$, in Chron C5Ar). The next two samples ex- amined at 686.20-693.59 mbsf did not contain T. rugosus, but were characterized by poor preservation. The next sample, the lowest to contain T. rugosus, was at 696.86 mbsf (Sample 157-953C-55R-1, 36 $\mathrm{cm})$. Samples directly below this sample were again poorly preserved and many have hindered the preservation and identification of this species. The lowest recorded occurrence is within Chron C5Ar at Site 953. This is a similar stratigraphic position as Site 845 (Pacific Ocean, Leg 138; Raffi and Flores, 1995), and Site 608 (North Atlantic; Olafsson, 1989, based on threshold abundance rather than actual lowest occurrence), but differs from Gartner's (1992) investigation of Site 608, which has the lowest occurrence in Chron C5AA, an older age. The presence of $T$. rugosus seems to be hampered by poor preservation, and, therefore, the range of T. rugosus at Site 953 may not reflect its full range. It's probably best not to use the lowest occurrence of this species for biostratigraphy at this site.

Typically, Zone CN5 is divided into a Subzones CN5b and CN5a, based on the FO of Discoaster kugleri. Many consider D. kugleri a poor marker (Gartner and Chow, 1985; Gartner, 1992; Fornaciari et al., 1990), because it is usually very rare, difficult to recognize when samples are overgrown, and has a discontinuous distribution. Secondary markers for the first occurrence of $D$. kugleri have been proposed, such as the last occurrence of Coronocyclus nitescens (Gartner and Chow, 1985), and the last occurrence of Cyclocargolithus floridanus (Bukry, 1973).

D. kugleri is present at Site 953, but typically, is very rare and has a discontinuous distribution. A highest occurrence of $D$. kugleri is observed at 543.74-543.76 mbsf, just below the lowest occurrence of C. coalitus (539.19-539.21 mbsf) in Chron C5n.2n. Bukry (1973), and Raffi and Flores (1995), both recorded the last specimens of $D$. 


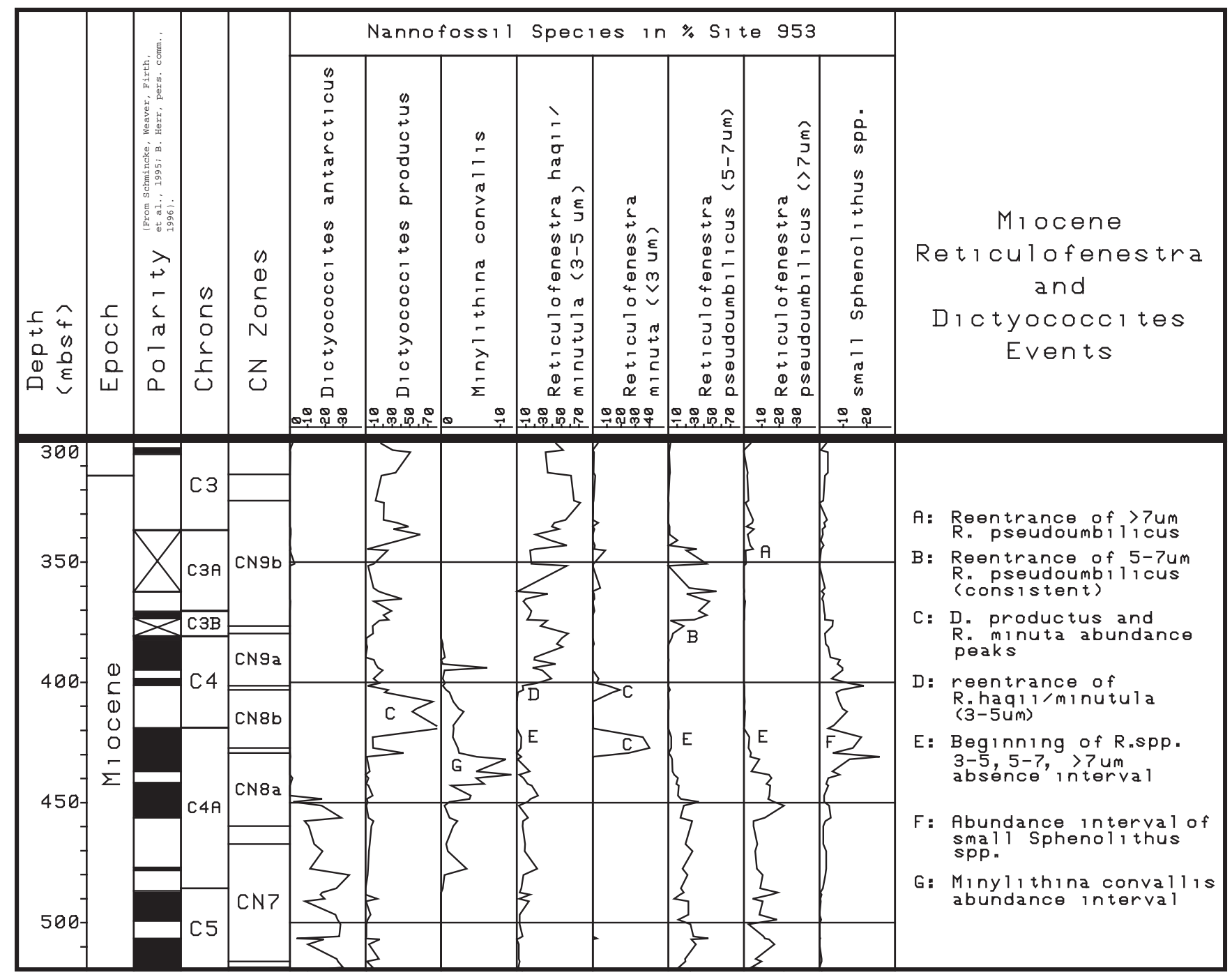

Figure 6. Percentage plots of upper Miocene nannofossil events.

kugleri close to the FO of $C$. coalitus. However, the highest consistent occurrence of D. kugleri was not until $581.48 \mathrm{mbsf}$ in Chron C5r.2r. Raffi and Flores (1995) recorded the common and continuous distribution of D. kugleri in Pacific Site 845 in C5r. The lowest consistent occurrence of D.kugleri at Site 953 was in a slumped interval interpreted to be Chron 5An.1n (623.35 mbsf, Sample 157-953C47R-4, $32 \mathrm{~cm})$. D. kugleri is present sporadically below this level. The lowest occurrence of $D$. kugleri does not seem to be a useful event here, however the highest "common" occurrence does seem to be useful.

The highest occurrence of $C$. nitescens was below the lowest consistent occurrence of D. kugleri. It should be noted that the specimens of $C$. nitescens were slightly oval in the latter part of its range.

Another event that takes place within Subzone CN5a is the lowest occurrence of $R$. pseudoumbilicus $(>7.0 \mu \mathrm{m})$. At Site 953 , this is not a clear, distinguishable event. Individual specimens just over $7 \mu \mathrm{m}$, occur very rarely down to $747.84 \mathrm{mbsf}$ in lower Subzone CN5a, Chron C5ABn. The lowest common abundance is in Subzone CN5b at 610.10 mbsf in Chron C5An.1n.

\section{Zone CN4}

The top of Zone CN4 is defined by the last occurrence of S. heteromorphus, and the bottom by the last occurrence of Helicosphaera ampliaperta. Both species are present at Site 953, thus allowing definition of this zone. The highest occurrence of $S$. heteromorphus is within Chron C5ABr.

Other distinctive events within Zone CN4 are the highest occurrence of Discoaster petaliformis in uppermost $\mathrm{CN} 4$, Chron C5ACn. D. petaliformis is easily recognized by its prominent stellate knob on one side. Its lowest occurrence at Site 953 is near the Zone CN4/CN3 boundary; however, this is probably not the full range of $D$. petaliformis because sample spacing near its lowest occurrence is wide, caused by abundant volcaniclastic material. Also within lower CN4 are the lowest occurrences of D. productus and D. antarcticus.

\section{Zone CN3}

The last occurrence of $H$. ampliaperta defines the top of Zone CN3. The highest occurrence of H. ampliaperta is at 968.15-968.16 mbsf. It is again observed at 968.22 mbsf. From 969.16 to $1152 \mathrm{mbsf}$, however, there is no biostratigraphic control. There is a thick sequence of hyaloclastic tuffs, lapillistones, and breccias from which nannofossils were not recovered. In the bottommost core at 1153.21 and $1153.215 \mathrm{mbsf}$, S. heteromorphus and H. ampliaperta are present, thus suggesting Zone CN3. It should be noted however, that the samples containing $S$. heteromorphus and $H$. ampliaperta were from a fairly chaotic sequence, and there is the possibility that they 
are reworked. If they are in place, it would indicate Zone CN3. Using the Berggren et al. (1995) time scale, Zone CN3 is middle to lower Miocene.

\section{SUMMARY}

In summary, a total of 57 calcareous nannofossil events for the Pleistocene to middle Miocene have been identified at Site 953 (Fig. 7). These events have been tied, where possible, to the paleomagnetic record of Schmincke, Weaver, Firth, et al. (1995), and B. Herr, pers. comm. (1996), and to the radiometric ages generated by Bogaard (Chap. 19, this volume). With the use of quantitative counting techniques, various trends within the nannofossil abundances were used to further resolve the biostratigraphic record.

In the Pleistocene, using the previously defined morphometric parameters for the Gephyrocapsa (Raffi et al., 1993), two small Gephyrocapsa intervals were identified. The first, originally described by Gartner (1977), is well documented worldwide. The second was noted by Firth and Isiminger-Kelso (1992) in the Pacific, and, although slightly different species criteria are used, can also be identified at Site 953 in the uppermost part of Subzone CN14a, from 0.7 to 0.54 Ma.

During the Pliocene, from 3.7 to 4.2 Ma (Chron C2Ar to C3n), a distinct abundance interval of small $(<3 \mu \mathrm{m})$ Gephyrocapsa species was documented. This is a discontinuous occurrence pattern at Site 953, because the Gephyrocapsa are then absent from 3.7 Ma to $\sim 2.5$ Ma. At $2.5 \mathrm{Ma}$, they again enter the stratigraphic record to eventually become the dominant form in the Pleistocene.

In the upper Miocene, using morphometrically defined criteria, the absence interval of the larger Reticulofenestra (Young, 1990; Rio et al., 1990) was identified. Within this absence interval, there is an increase in both small Reticulofenestra $(<3 \mu \mathrm{m})$ and in D. productus. Also overlapping with these productivity peaks are increases in small Sphenolithus species.

Although the focus of this paper was biostratigraphic, not paleooceanographic, a trend within $C$. pelagicus suggests a period of cooler water from $\sim 3.28$ to $2.36 \mathrm{Ma}$, probably related to the initiation of Northern Hemisphere glaciation and an expansion of the cooler water, upwelling zone of the Canary Current.

\section{ACKNOWLEDGMENTS}

The authors would like to thank Peter Griggs for technical assistance with the RAGWARE plotting program, Glenn Merrill at the University of Houston for use of the SEM, and Bill Fenner and Lori Glassgold at Shell Western E\&P, Inc., for use of their library and computer facilities. We gratefully thank Wuchang Wei and Woody Wise for their constructive suggestions for improving the manuscript. R. Howe was supported by the European Community MAST program (STEAM project MAS2-CT94-0083) and J. Sblendorio-Levy was supported by JOI U.S. Science Support Program Grant \#15720849b.

\section{REFERENCES}

Backman, J., and Shackleton, N.J., 1983. Quantitative biochronology of Pliocene and early Pleistocene calcareous nannofossils from the Atlantic, Indian and Pacific oceans. Mar. Micropaleontol., 8:141-170.

Berggren, W.A., Kent, D.V., Swisher, C.C., III, and Aubry, M.-P., 1995. A revised Cenozoic geochronology and chronostratigraphy. In Berggren, W.A., Kent, D.V., Aubry, M.-P., and Hardenbol, J. (Eds.), Geochronology, Time Scales and Global Stratigraphic Correlation. Spec. Publ.Soc. Econ. Paleontol. Mineral., 54:129-212.

Bukry, D., 1973. Low-latitude coccolith biostratigraphic zonation. In Edgar, N.T., Saunders, J.B., et al., Init. Repts. DSDP, 15: Washington (U.S. Govt. Printing Office), 685-703.
Dennison, J.M., and, Hay, W.W., 1967. Estimating the needed sampling area for subaquatic ecologic studies. J. Paleontol., 41:706-708.

Firth, J.V., and Isiminger-Kelso, M., 1992. Pleistocene and OligoceneMiocene calcareous nannofossils from the Sumisu Rift and Izu-Bonin forearc basin. In Taylor, B., Fujioka, K., et al., Proc. ODP, Sci. Results, 126: College Station, TX (Ocean Drilling Program), 237-262.

Fornaciari, E., Raffi, I., Rio, D., Villa, G., Backman, J., and Olafsson, G., 1990. Quantitative distribution patterns of Oligocene and Miocene calcareous nannofossils from the western equatorial Indian Ocean. In Duncan, R.A., Backman, J., Peterson, L.C., et al., Proc. ODP, Sci. Results, 115: College Station, TX (Ocean Drilling Program), 237-254.

Gartner, S., 1992. Miocene nannofossil chronology in the North Atlantic, DSDP Site 608. Mar. Micropaleontol., 18:307-331.

Gartner, S., Jr., 1977. Calcareous nannofossil biostratigraphy and revised zonation of the Pleistocene. Mar. Micropaleontol., 2:1-25.

Gartner, S., and Chow, J., 1985. Calcareous nannofossil biostratigraphy, Deep Sea Drilling Project Leg 85, eastern equatorial Pacific. In Mayer, L., Theyer, F., Thomas, E., et al., Init. Repts. DSDP, 85: Washington (U.S. Govt. Printing Office), 609-619.

Hay, W.W., and Beaudry, F.M., 1973. Calcareous nannofossils--Leg 15 , Deep Sea Drilling Project. In Edgar, N.T., Saunders, J.B., et al., Init. Repts. DSDP, 15: Washington (U.S. Govt. Printing Office), 625-683.

Martini, E., 1971. Standard Tertiary and Quaternary calcareous nannoplankton zonation. In Farinacci, A. (Ed.), Proc. 2nd Int. Conf. Planktonic Microfossils Roma: Rome (Ed. Tecnosci.), 2:739-785.

McIntyre, A., and Bé, A.W.H., 1967. Modern coccolithophoridae of the Atlantic Ocean. I: placoliths and cyrtoliths. Deep-Sea Res. Part A, 14:561-597.

Okada, H., and Bukry, D., 1980. Supplementary modification and introduction of code numbers to the low-latitude coccolith biostratigraphic zonation (Bukry, 1973; 1975). Mar. Micropaleontol., 5:321-325.

Olafsson, G., 1989. Quantitative calcareous nannofossil biostratigraphy of upper Oligocene to middle Miocene sediment from ODP Hole 667A and middle Miocene sediment from DSDP Site 574. In Ruddiman, W., Sarnthein, M., et al., Proc. ODP, Sci. Results, 108: College Station, TX (Ocean Drilling Program), 9-22.

Raffi, I., Backman, J., Rio, D., and Shackleton, N.J., 1993. Plio-Pleistocene nannofossil biostratigraphy and calibration to oxygen isotopes stratigraphies from Deep Sea Drilling Project Site 607 and Ocean Drilling Program Site 677. Paleoceanography, 8:387-408.

Raffi, I., and Flores, J.-A., 1995. Pleistocene through Miocene calcareous nannofossils from eastern equatorial Pacific Ocean (Leg 138). In Pisias, N.G., Mayer, L.A., Janecek, T.R., Palmer-Julson, A., and van Andel, T.H. (Eds.), Proc. ODP, Sci. Results, 138: College Station, TX (Ocean Drilling Program), 233-286.

Rio, D., 1982. The fossil distribution of coccolithophore genus Gephyrocapsa Kamptner and related Plio-Pleistocene chronostratigraphic problems. In Prell, W.L., Gardner, J.V., et al., Init. Repts. DSDP, 68: Washington (U.S. Govt. Printing Office), 325-343.

Rio, D., Fornaciari, E., and Raffi, I., 1990. Late Oligocene through early Pleistocene calcareous nannofossils from western equatorial Indian Ocean (Leg 115). In Duncan, R.A., Backman, J., Peterson, L.C., et al., Proc. ODP, Sci. Results, 115: College Station, TX (Ocean Drilling Program), 175-235.

Ruddiman, W.F., Backmann, J., Baldauf, P., Hooper, L., Keigwin, K., Miller, K., Raymo, M., and Thomas, E., 1987. Leg 94 paleoenvironmental synthesis. In Ruddiman, W.F. Kidd, R.B., Thomas, E., et al., Init. Repts. $D S D P$, 94: Washington (U.S. Govt. Printing Office), 1207-1215.

Sato, T., and Takayama, T., 1992. A stratigraphically significant new species of the calcareous nannofossil Reticulofenestra asanoi. In Ishizaki, K., and Saito, T. (Eds.), Centenary of Japanese Micropaleontology: Tokyo (Terra Sci. Publ.), 457-460.

Schmincke, H.-U., Weaver, P.P.E., Firth, J.V., et al., 1995. Proc. ODP, Init. Repts., 157: College Station, TX (Ocean Drilling Program).

Shipboard Scientific Party, 1995. Site 953. In Schmincke, H.-U., Weaver, P.P.E., Firth, J.V., et al., Proc. ODP, Init. Repts., 157: College Station, TX (Ocean Drilling Program), 317-394.

Takayama, T., 1993. Notes on Neogene calcareous nannofossil biostratigraphy of the Ontong Java Plateau and size variations of Reticulofenestra coccoliths. In Berger, W.H., Kroenke, L.W., Mayer, L.A., et al., Proc. ODP, Sci. Results, 130: College Station, TX (Ocean Drilling Program), $179-229$.

Takayama, T., and Sato, T., 1987. Coccolith biostratigraphy of the North Atlantic Ocean, Deep Sea Drilling Project Leg 94. In Ruddiman, W.F., 
Kidd, R.B., Thomas, E., et al., Init. Repts. DSDP, 94 (Pt. 2): Washington (U.S. Govt. Printing Office), 651-702.

Theodoridis, S., 1984. Calcareous nannofossil biozonation of the Miocene and revision of the helicoliths and discoasters. Utrecht Micropaleontol. Bull., 32:1-271.

Young, J.R., 1990. Size variation of Neogene Reticulofenestra coccoliths from Indian Ocean DSDP cores. J. Micropaleontol., 9:71-85.

Young, J.R., Flores, J.-A., and Wei, W., 1994. A summary chart of Neogene nannofossil magnetobiostratigraphy. J. Nannoplankton Res., 16:21-27.

Date of initial receipt: 26 June 1996

Date of acceptance: 8 January 1997

Ms 157SR-107

\section{APPENDIX}

Calcareous nannofossils considered in this chapter listed alphabetically.

Amaurolithus amplificus (Bukry and Percival, 1971) Gartner and Bukry, 1975 Amaurolithus delicatus Gartner and Bukry, 1975

Amaurolithus primus (Bukry and Percival, 1971) Gartner and Bukry, 1975

Amaurolithus tricorniculatus (Gartner, 1967) Gartner and Bukry, 1975

Braarudosphaera bigelowii (Gran and Braarud, 1935) Deflandre, 1947

Calcidiscus leptoporus (Murray and Blackman, 1898) Loeblich and Tappan, 1978

Calcidiscus macintyrei (Bukry and Bramlette, 1969) Loeblich and Tappan, 1978

Calcidiscus premacintyrei Theodoridis, 1984

Calcidiscus tropicus Kamptner, 1955 sensu Gartner, 1992 Plate II, figure 4

Catinaster calyculus Martini and Bramlette, 1963

Catinaster coalitus Martini and Bramlette, 1963

Ceratolithus acutus Gartner and Bukry, 1974

Ceratolithus cristatus Kamptner, 1950

Ceratolithus rugosus Bukry and Bramlette, 1968

Coccolithus miopelagicus Bukry, 1971

Coccolithus pelagicus (Wallich, 1877) Schiller, 1930

Coccolithus pliopelagicus Wise, 1973

Coronocyclus nitescens (Kamptner, 1963) Bramlette and Wilcoxon, 1967

Coronocyclus protoannula (Kamptner, 1963) Bramlette and Wilcoxon, 1967 Cryptococcolithus takayamae Gartner, 1992

Cyclicargolithus floridanus (Roth and Hay in Hay et al., 1967) Bukry, 1971

Dictyococcites antarcticus Haq, 1976

Dictyococcites productus (Kamptner, 1963) Backman, 1980

Discoaster asymmetricus Gartner, 1969

Discoaster bellus Bukry and Percival, 1971

Discoaster berggrenii Bukry, 1971

Discoaster blackstockae Bukry, 1973

Discoaster bollii Martini and Bramlette, 1963

Discoaster braarudii Bukry, 1971

Discoaster brouweri Tan (1927) emend. Bramlette and Riedel, 1954

Discaster calcaris Gartner, 1967

Discoaster challengeri Bramlette and Riedel, 1954

Discoaster deflandrei Bramlette and Riedel, 1954

Discoaster exilis Martini and Bramlette, 1963

Discoaster hamatus Martini and Bramlette, 1963

Discoaster intercalaris Bukry, 1971

Discoaster kugleri Martini and Bramlette, 1963

Discoaster loeblichii Bukry, 1971

Discoaster mendomobensis Wise, 1973

Discoaster moorei Bukry, 1971

Discoaster neohamatus Bukry and Bramlette, 1969

Discoaster pansus (Bukry and Percival, 1971) Bukry, 1973

Discoaster pentaradiatus Tan (1972) emend. Bramlette and Riedel, 1954

Discoaster petaliformis Moshkovitz and Ehrlich, 1980
Discoaster prepentaradiatus Bukry and Percival, 1971

Discoaster pseudovariabilis Martini and Worsley, 1971

Discoaster quinqueramus Gartner, 1969

Discoaster signus Bukry, 1971

Discoaster surculus Martini and Bramlette, 1963

Discoaster tamalis Kamptner, 1967

Discoaster triradiatus Tan, 1927

Discoaster variabilis Martini and Bramlette, 1963

Discosphaera tubifer (Murray and Blackman, 1898) Ostenfeld, 1900

Emiliania huxleyi (Lohmann, 1902) Hay and Mohler in Hay et al., 1967

Florisphaera profunda Okada and Honjo, 1973

Gephyrocapsa caribbeanica Boudreaux and Hay, 1969

Gephyrocapsa oceanica Kamptner, 1943

Gephyrocapsa parallela Hay and Beaudry, 1973

Hayaster perplexus (Bramlette and Riedel, 1954) Bukry, 1973

Helicosphaera acuta Theodoridis, 1984

Helicosphaera ampliaperta Bramlette and Wilcoxon, 1967

Helicosphaera carteri (Wallich, 1877) Kamptner, 1954

Helicosphaera carteri var. wallichii (Lohmann, 1902) Theodoridis, 1984

Helicosphaera colombiana Gartner, 1977

Helicosphaera elongata Theodoridis, 1984

Helicosphaera euphratis Haq, 1966

Helicosphaera granulata (Bukry and Percival, 1973) Jafar and Martini, 1975

Helicosphaera hyalina Gaarder, 1970

Helicosphaera inversa (Gartner, 1977) Theodoridis, 1984

Helicosphaera mediterranea Müller, 1981

Helicosphaera neogranulata Gartner, 1977

Helicosphaera orientalis Black, 1971

Helicosphaera pacifica Müller and Brönnimann, 1974

Helicosphaera paleocarteri Theodoridis, 1984

Helicosphaera pavimentum Okada and McIntyre, 1977

Helicosphaera perch-nielseniae Haq, 1971

Helicosphaera rhomba Bukry, 1971

Helicosphaera scissura Miller, 1981

Helicosphaera sellii Bukry and Bramlette, 1969

Helicosphaera stalis Theodoridis, 1984

Helicosphaera walbersdorfensis Müller, 1974

Helicosphaera waltrans Theodoridis, 1984

Holodiscolithus macroporus (Deflandre in Deflandre and Fert, 1954) Roth, 1970

Minylitha convallis Bukry, 1973

Oolithotus fragilis (Lohmann, 1912) Martini and Müller, 1972

Pseudoemiliania lacunosa (Kamptner, 1963) Gartner, 1969

Reticulofenestra asanoi Sato and Takayama, 1992

Reticulofenestra haqii Backman, 1978

Reticulofenestra minuta Roth, 1970

Reticulofenestra minutula (Gartner, 1967) Haq and Berggren, 1978

Reticulofenestra pseudoumbilica (Gartner, 1967) Gartner, 1969

Reticulofenestra rotaria Theodoridis, 1984

Scapholithus fossilis Deflandre in Deflandre and Fert, 1954

Scyphosphaera amphora Deflandre, 1942

Scyphosphaera globulata Bukry and Percival, 1971

Scyphosphaera pulcherrima Deflandre, 1942

Scyphosphaera ventriosa Martini, 1968

Sphenolithus abies Deflandre in Deflandre and Fert, 1954

Sphenolithus compactus Backman, 1980

Sphenolithus conicus Bukry, 1971

Sphenolithus heteromorphus Deflandre, 1953

Sphenolithus moriformis (Brönnimann and Stradner, 1960) Bramlette and Wilcoxon, 1967)

Tetralithoides symeonidesii Theodoridis, 1984

Triquetrorhabdulus carinatus Martini, 1965

Triquetrorhabdulus finifer Theodoridis, 1984

Triquetrorhabdulus rugosus Bramlette and Wilcoxon, 1967

Umbilicosphaera sibogae (Weber-van Bosse, 1901) Gaarder, 1970 


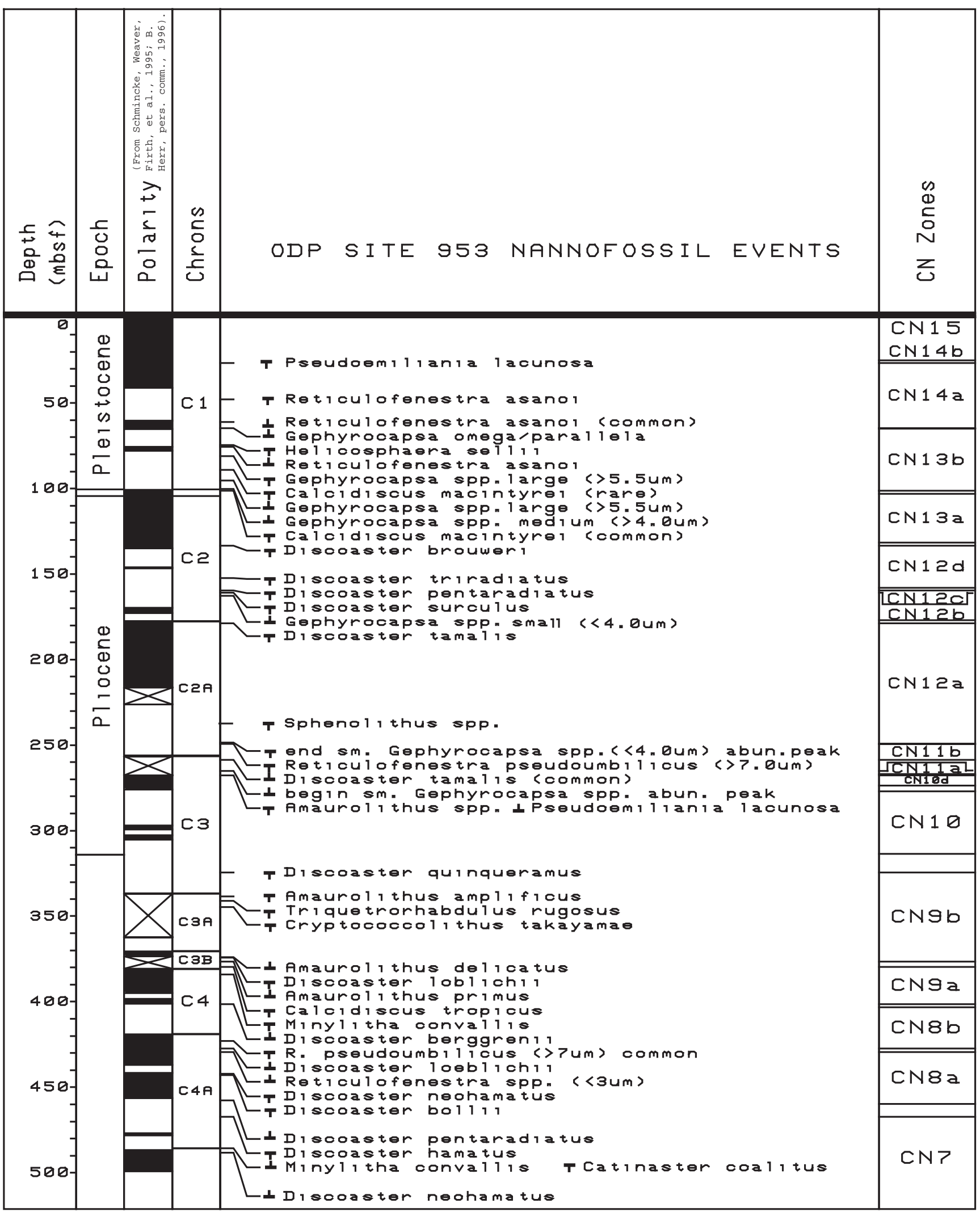

Figure 7. Summary chart of nannofossil events at Site 953. 


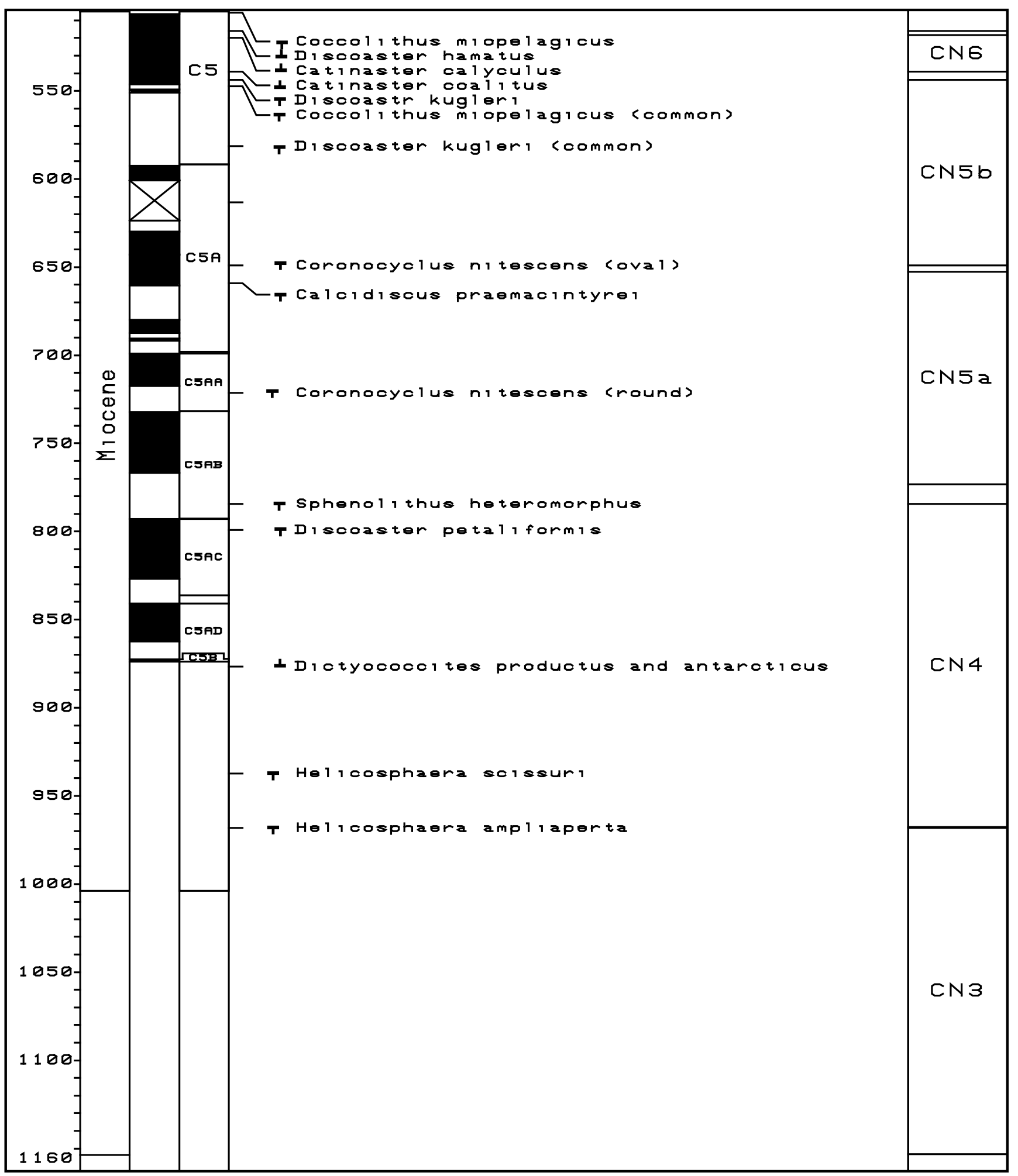

Figure 7 (continued). 